\section{Changes in Responsibilities and Tasks of Universities in Regional Innovation Ecosystems}

\author{
Zoltán Birkner \\ University of Pannonia, Hungary \\ birkner.zoltan@uni-pen.hu \\ Tivadar Máhr \\ University of Pannonia, Hungary \\ mahrtivadar@gmail.com \\ Nora Rodek Berkes \\ University of Pannonia, Hungary \\ rodek.nora@uni-pen.hu
}

\begin{abstract}
Innovation process research is changing. In addition to the former territorial approach (examining countries or regions), the description of innovation cooperation in local areas is becoming more and more accepted. Instead of the innovation ability of the traditional large enterprises, research has begun to study the role of small and medium-sized enterprises, non-governmental organizations, local governments, and educational institutions (especially universities), which foreshadows the development of a new innovation system. In 2015, we conducted a study focusing on the civil and corporate relations of a major university. We tried to determine the new directions based on the economic and social cooperation as well as to search for the practical implementation of the theoretical helixes in these interactions. We came to the conclusion that universities not only are determinative according to the triple helix model but also have a prominent role in the creation of new innovation ecosystems, particularly in a well-defined geographical area.
\end{abstract}

Keywords: Helix models, innovation, social innovation, university relations

\section{Introduction}

The University of Pannonia (a prestigious academic institution in Hungary) was based on an excellent chemical specialist university with good organization and engineering thinking, which had real connections to the industry's big players and gave sector research and knowledge to its market and social partners. This origin still has a positive impact on the university relations. However, the growth of the university also brought the appearance of new disciplines with, therefore IT, engineering and environmental science have been included among the focus areas.

Universities operate in a constantly changing environment. To undersetand the role of a university as a knowledge centre, it is necessary to assess the research competencies and relations of the institution as well as the selected strategic directions in the field of cooperation and the preparation for their implementation.
ORIGINAL SCIENTIFIC PAPER

RECEIVED: NOVEMBER 2016

REVISED: APRIL 2017

ACCEPTED: APRIL 2017

DOI: 10.1515/ngoe-2017-0008

UDK: 332.12:378

JEL: 035

Citation: Birkner, Z., Máhr, T., \& Rodek Berkes, N. (2017). Changes in Responsibilities and Tasks of Universities in Regional Innovation Ecosystems. Naše gospodarstvo/Our Economy, 63(2), 15-21. DOI: 10.1515/ ngoe-2017-0008

\section{NG OE}

NAŠE GOSPODARSTVO OUR ECONOMY

\section{Vol.63 No.2 2017}

pp. $15-21$ 
A survey was carried out in two stages in 2015 to explore the function of the University of Pannonia as a knowledge centre. The research questions were as follows:

- Has the emergence of new disciplines transformed the corporate and social relations of the institution?

- Were there any changes in the way of building relationships? Can this method be further developed?

- Do the new partners also participate in social innovation processes in addition to the traditional (technological) innovation objectives?

To answer these questions, we considered it necessary to examine innovation cooperation in the preceding three and a half years (from January 2012 to June 2015). A total of 173 contracts were found (together with the project and legal experts of the university, we selected contracts linked to the R \& D \& I areas). We paid special attention to the competitive tenders that represent new and very important complements of the traditional partnerships. These competitive tenders are important individually as well, because they were intended to solve innovation tasks. The partners and the applications were selected on the basis of a very significant public and scientific filter. After a detailed analysis of the contracts, qualitative studies were carried out on the basis of the results. In terms of the project activity, the most successful university departments, the institution leaders and the researchers responsible for the work specified in the contracts were interviewed (a total of ten colleagues). Our aim was to carry out deeper studies in the field of preparing contracts, their content and the method of networking. Based on the results of the above-mentioned studies, we identified the economic and social innovations that are specific to the university and its partners. We tried to answer the question of whether the responsibility and tasks of the university have changed in the regional innovation ecosystems.

\section{Theoretical Background}

Innovation has become one of the most important sources of the national and regional economy growth in the past decades. Subsequently, the unveiling of innovation processes, the recognition of entities involved in renovation, and research on relations and influencing factors have become more and more important. Innovation is, according to the literature, the ability to do things in a new way (Schumpeter, 1939), a change that unveils new dimensions of performance (Drucker, 2003), or a creative idea (Karlsson-Johansson, 2004).

Porter (1985) considers innovation to be a series of small development steps that provide the opportunity for continuous competitive advantage. The term innovation has become ever more widespread in disciplines other than economics; therefore, it is often used in the interpretation of social, educational, environmental and social changes. Thus, it became necessary to define the areas of renewal (Oslo Manual). The major novelty of the 2005 edition of the Oslo Manual is that the activities of organisation development and marketing are listed among the innovation areas. "An innovation is the implementation of a new or significantly improved product (good or service), or process, a new marketing method, or a new organizational method in business practices, workplace organization or external relations" (Oslo Mamual, 2005, $3^{\text {rd }}$ edition, p.46). This is the most accepted and used definition for innovation in Europe, and its strength is that it can be interpreted for organisations other than economic ones.

The so-called triple helix model of Etzkowitz and Leyersdorf (2000) is an outstanding model demonstrating the innovation process. It describes a common, development-based interactive relation among the three institution types (state, enterprise, university). The correlations between the constituents of the model bolster the various levels of the circulatory system. The key to development is the reduction of factors hindering development, by means of which there is an increased movement in the system, thus opening the way to sustainable development. The supporting role of the state must receive special attention.

There were initiatives to further expand and develop the triple helix model. The existence of a fourth helix appeared (Etzkowitz-Zhous, 2006). In connection with this, suggestions were made of factors influencing innovations, such as labour, risk capital, informal sectors and civic society. Carayannis and Campbell (2009) created a model by thinking about the triple-helix model further and reasoning that the media and culture-based community space appear as the fourth helix. Through the appearance of the new elements it becomes evident that the members of society and communities are linked to business, technical, service and scientific areas; thus, the NGO sphere has a link to the university-industry-government correlation.

Further consideration of the quadruple helix led to the birth of the fifth helix (Carayannis et al., 2010). From this point onwards, the literature differentiates between the social and economic environment, with the ecological aspect suggesting a unified approach with regard to the natural environment, social environment and economic development in such a way that innovation must be used to achieve sustainable social and economic change (also in the case of different regional levels).

In summary of the helix-related literature, we believe that sustainable development technology stands in the centre of the triple helix innovation model, while the fourth helix 
highlights the role of the civil society. The fifth helix adds the ecological approach to the previous models. These extensions indicate that the surface of the interpretation of innovation is growing. In addition to the technological objectives, social and environmental tasks also appear. The concept of social innovation tries to deal with the emergence of these extensions.

Mulgan et al. (2007) regard social innovation as a series of innovative activities and services, which are meant to fulfil certain social needs and which are developed and spread by organisations whose primary goal is the well-being of the society. One of the tasks of social innovation is to solve the new social and environmental problems created by social-economic changes by means of social tools (Szörényiné, 2015).

Territoriality is a key constituent of the innovation processes (Birkner-Lehota-Torma, 2013), as there are huge differences based on the spatial imbalances of access to knowledge (Vas-Bajmócy, 2012). Therefore, the regional research on innovation systems is an important approach (Dőry-Rechnitzer, 2000; Cooke, 2001).

The regional innovation system is capable of using the locally available, created knowledge elements typical of a given region. The basic condition hereof is the territorial proximity and the existence and utilisation of interpersonal connection systems (Hau-Horváth - Horváth, 2014). The regional/territorial innovation system includes universities, as elements of the technological offering, as well as research institutes and innovative enterprises, their activities and the connections established among them.

There is an ever-increasing pressure on universities by local interested parties for the sake of coordinating their basic needs with the demands of the region (Chatterton-Goddard, 2000). Bramwell et al. (2012) claim that universities are the motors of regional economic development. The local devotion of universities can bolster the well-being of its environment in many ways, including research, infrastructure development, education, innovation, efficient university-business relations and community development. Therefore, universities undertake the third mission (i.e., the role of development) apart from research and education. When the universities integrate into their own region, they have an obvious impact on the intensity and character of potential relations and thus on the process of spreading knowledge (Gál-Zsibók, 2013). A young academic institution can remain competitive and viable only if it is open to the market and local needs (Kaszás et al., 2015, p. 368).

Researchers investigating the role of small- and medium-sized universities in the Central-East-European region concluded that the role of universities away from cities is crucial in the regional system of innovation; however, the economic impact of these universities is still smaller than that in more developed countries (Gál-Ptacek, 2011; Ernszt et al., 2015, Birkner-Mahr, 2016). Universities with their connections can be the engines of development in these territories. Overall, we can say that with the effective contribution of universities, increasingly complex relationship systems can be created, building new local / regional innovation ecosystems.

\section{Methodology and Results}

Before the general analysis, we hypothesized that the research development co-operations of the five-faculty university had moved away from traditional relationships in the chemical industry and that it would be possible to observe the new scientific areas. Specifically, the following hypothesis was formulated:

H: The new disciplines have significant weight in the R \& D \& I contracts, based on the number and value of the contracts these are the most important relationships today.

We also thought that meeting the demands of the civil society and local government, as well as developing the ecological approach, would be issues that would arise in the innovative research, so we expected to find examples of these issues in the contracts as well.

The data partially confirmed the hypothesis, since there is more cooperation with IT, engineering and agriculture in terms of number of pieces; however, by far the largest number of service users are those major organizations from the past with which the university had a prior relationship. The environmental industry contracts are also important; these are partly the products of the chemical past, but there are also sustainability-related research studies that can be interpreted as results of the fifth helix. The classic civil or government needs did not appear in the direct form (with one exception) by independent contracts, but we found examples of this as well in the concluded cooperation. The agreements were made for a 5.5-month period on average, but in the case of the major contracts a yearly period was typical. Longer studies and works are typical in big-scale tenders.

It can be established from the database that, in terms of geographical location, the university carried out the majority of the contracts with firms in Budapest, the capital of Hungary, while the rest were completed with companies operating in Transdanubian settlements. Regarding the geographical location of the University of Pannonia, this result is not 
Table 1: Types of R \& D \& I Contracts of the University of Pannonia

\begin{tabular}{lrrrr} 
Types of contracts & $\begin{array}{r}\text { Number of } \\
\text { contracts (piece) }\end{array}$ & $\begin{array}{r}\text { Ratio of the number } \\
\text { of contracts (\%) }\end{array}$ & $\begin{array}{r}\text { Amount } \\
(\text { EUR) }\end{array}$ & $\begin{array}{r}\text { Ratio of the total } \\
\text { contracts (\%) }\end{array}$ \\
\hline Environmental Protection,environmental industry & 27 & $16 \%$ & 382.512 & $14 \%$ \\
\hline Engineering, mechanical engineering & 9 & $5 \%$ & 162.293 & $6 \%$ \\
\hline IT & 18 & $10 \%$ & 612.100 & $22 \%$ \\
\hline Agriculture & 78 & $45 \%$ & 246.533 & $9 \%$ \\
\hline Chemical industry & 40 & $23 \%$ & 1348.187 & $48 \%$ \\
\hline Other (results of social relations) & 1 & $1 \%$ & 33.386 & $1 \%$ \\
\hline Total & 173 & $100 \%$ & 2784.961 & $100 \%$ \\
\hline
\end{tabular}

surprising. Moreover, it is almost a platitude that numerous companies located in the country deal with the innovation contracts at their centre in Budapest. The tenders that focused on competitiveness (a total of 3 pieces out of the 173 contracts that were concluded) showed a very interesting one-sided nature. The university was able to win such big-scale tenders only in the field of informatics. This is a positive process because, through this process, the building and strengthening of the new areas is verified, and it is possible to detect the commitment of the university management. The tenders focused on competitiveness were significantly different from the traditional R\&D cooperation, as they can be characterized by the much larger research tasks and amounts of money assigned to them, the investor is the Hungarian state, the leaders of the consortium are world-class large enterprises, and the duration of the tenders is usually 3-4 years. In the case of a traditional $R \& D$, the university fulfills an order coming from the market, while in the case of a tender focused on competitiveness, all the beneficiaries realize their 'own' R\&D tasks during the course of the project. The relationships pertaining to competitiveness are built over a long period of time, and the partners have to know each other well, while the normal R\&D can be a one-time or unique order.

Following the general analysis of the contracts, we contacted those actors who were successful in the development of innovation relations and task execution, and we formulated the following research question:

Are the existing personal relationships important in the innovation co-operation, and do the companies expect a professional project approach from the universities in the case of R \& D \& I work?

We asked the respondents ten questions. The most important results are briefly presented below. The colleagues typically gave two types of answers to the question of 'How are the corporate relationships established?' and 'How are relationships built?' These two types of answers are as follows:
- The corporate co-operations are primarily established through personal relationships (with graduated students and ex-colleagues from the university employed at firms as well as the relationship networks of the engineers and professors at the university). Trust, professional quality and authenticity as well as the reference created on the basis of the successfully implemented and closed projects' results are important.

- We put a lot of effort into expanding research development by visiting and getting to know the firms of the region, in terms of who has what motivations and in which projects they are interested.

Based on the responses, we can state that the personal relationships are still important in the development of innovation co-operation, which partially answers our research question. However, a small addition should be made to the statement, as the establishment of new relationships requires substantial extra energy from the university.

The process of communication is successful if the organizations speak to each other about the advantages of co-operation with the university, such as at professional conferences or during university workshops. We have made and continuously upgraded a list of the corporate cooperations in progress, tracing their advancements. The connection with a university is important for the organizations because they look for knowledge and capacity as well as experts through whose involvement they can expand their knowledge or realize developmental tasks for which their financial resources are not enough. The relationships are advantageous for the university, as industrial research comes before academic research; thus, through $\mathrm{R} \& \mathrm{D}$ cooperation it is possible to change the teaching-learning material in a forward-looking way, according to the demands of the industry.

For the question of what expectations / conditions the companies have before the university co-operation, the respondents answered as follows: in the case of the company's expectations, it is very important for operation to be clear, 
explicit, and project-based; for the legal environment to be free from unnecessary administration and bureaucracy; for there to be continuous communication; and recording the business interest systems and the co-operation forms. Based on these answers, we can confirm that the companies really expect professional operation from the university in the innovation work.

The name of the university or even a professor used to be a satisfactory condition for the partner. Today, however, more and more requirements have to be met. The participants expect a working team to solve the emerging issues.

Respondents gave the following answer to the question of 'How typical are the local, regional co-operations?' Regarding the fact that only a few capital-intensive enterprises and NGOs can be found in the area (around Veszprém) related to our research topic, the partners of national importance are rather determinative in the relationship network.

The answers to the question of 'How can these relationships be developed?' prescribe tasks for the university management:

- Whether universities organize R\&D projects within or outside the university has a determinative importance from the point of view of the relationships between companies, universities and NGOs. To keep the relationships of the University inside the institution, it is necessary to create an innovation system as well as a structural operation and business co-operation culture (legal and financial work processes), which supports the inward direction.

- A university business model does not exist in which certain persons (instructors, researchers, managers) and the partners can serve their interests while the university interests are not impaired. Furthermore, the revenues of the university increase (these are the characteristics of a good business model).

\section{Conclusion}

One of the most important areas of innovation is knowledge creation, which is impossible without the institutions of tertiary education. In accordance with this, the University of Pannonia plays an outstandingly important role in this field in its surroundings and in the vicinity of the capital city, as can be deduced from the results of the research. The research portfolio of the university is under transformation. In the case of the tenders focused on competitiveness, the developments in informatics have appeared markedly. These developments also support social innovation, as the relationship building between the actors has become simplified. The university builds its direct partnership through its graduated students as well as its instructors and researchers. This trust relationship greatly contributes to the opportunity for the organizations and the University to find common interfaces in other fields of social innovation, such as through social responsibility, social sensitivity, and civil relationships as well as the intellectual approach to sustainable development. It should be emphasized that the direct social and local NGOs have no significant presence on the customer side; the surveys and interviews have shown only indirect contacts for the time being. The development of the university, the increasing number of employees and its scientific results influence the local and national strengthening of social innovation. Building the innovational ecosystem is outstanding among the desired improvements, which allows the internal operating system and external relations of the university to become sensitive to innovation. This idea greatly supports the development of social innovation in the environment of the institution. Finally, we can say that the constant changes are forcing the market and university actors toward openness, to a new type of communication and everyday development; this is the basis of innovation. In this new space, the tasks, responsibilities and relationships will change, requiring the adequate adaptation of the examined higher education institution.

\section{References}

Andersson, M., \& Karlsson, C. (2004). Regional innovation systems in small \& medium- sized regions.. In The emerging digital economy: Entrepreneurship, clusters and policy (pp. 55-81) Berlin: Heidelberg, Springer. DOI 10.1007/3-540-34488-8_4 https://doi.org/10.1007/3-540-34488-8_4

Birkner, Z., Lehota, J., \& Torma, R. (2013). Unlimited opportunities (In Hungarian: Határtalan lehetőségek), Vezetéstudomány/Budapest Management Review, 44, 80-86.

Birkner, Z., \& Mahr, T. (2016). Interpreting innovation in another way. Vezetéstudomány/Budapest Management Review, 47(10), 39-50.

Bramwell, A., Hepburn, N., \& Wolfe, D. A. (2012). Growing innovation ecosystems: University-industry knowledge transfer and regional economic development in Canada. Final Report to the Social Sciences and Humanities Research Council of Canada, University of Toronto.

Carayannis, EG, \& Campbell, DFJ (2010). Triple Helix, Quadruple Helix and Quintuple Helix and how do knowledge, innovation and the environment relate to each other? A proposed framework for a trans-disciplinary analysis of sustainable development and social ecology. International Journal of Social Ecology and Sustainable Development, 1(1), 41-69. http://www.igi-global.com/bookstore/ article.aspx?titled=41959. https://doi.org/10.4018/jsesd.2010010105 
Carayannis, Elias G., David F. J. Campbell (2009). “Mode 3” and “Quadruple Helix”: Toward a 21st Century Fractal Innovation Ecosystem. International Journal of Technology Management. 46 (3/4), 201-234 (http://www.inderscience.com/browse/index.php?journalID=27\&year=2009\&vol=46\&issue=3/4). https://doi.org/10.1504/IJTM.2009.023374

Chatterton, P., \& Goddard, J. (2000). The response of higher education institutions to regional needs. European Journal of Education, 4 , 475-496. DOI: 10.1111/1467-3435.00041 https://doi.org/10.1111/1467-3435.00041

Cooke, P. (2001). Regional innovation systems, clusters and the knowledge economy. Industrial and Corporate Change, 10(4), $945-974$. DOI: 10.1093/icc/10.4.945 https://doi.org/10.1093/icc/10.4.945

Döry, T., \& Rechnitzer, J. (2000). Regional Innovation Strategies. (In Hungarian: Regionális innovációs stratégiák). Budapest. Oktatási Minisztérium (Ministry of Education), p.112

Drucker, P. F. (2003). Innovation Opportunities. (In Hungarian: Az innováció lehetőségei). Harvard Businessmanager, 5-6.sz., pp.28-34.

Etzkowitz, H., \& Leydesdorff, L. (2000). The dynamics of innovation: From national systems and “Mode2" to a triple helix of university-industry-government relations. Research Policy, 29(2). DOI: 10.1016/S0048-7333 (99)00055-4

Etzkowitz, H., \& Zhou, C. (2006). Triple helix twins: innovation and sustainability. Science and Public Policy, 33. DOI: $10.3152 / 147154306781779154$ https://doi.org/10.3152/147154306781779154

Gál,Z., \& Zsibók,Z. (2013). Engaging universities in regional innovation systems and innovation governance. (In Hungarian: Az egyetemek szerepvállalása a regionális innovációs rendszerekben és az innovációs kormányzásban) In: Innovation-Friendly Governance in Hungary (In Hungarian: Innovációbarát kormányzás Magyarországon), ed. Gál Z. 2013, pp. 187-221

Gál, Z., \& Ptácek, P. (2011). The role of mid-range universities in knowledge transfer in non-metropolitan regions in Central Eastern Europe. European Planning Studies, 9, 1669-1690. https://doi.org/10.1080/09654313.2011.586186

Hau-Horváth, 0., \& Horváth, M. (2014). The role of geographic proximity in innovation co-operation - an illusion or a real factor? (In Hunfarian: A földrajzi közelség szerepe az innovációs együttműködésekben - illúzió vagy valós tényező?), In: Economic Review (In Hungarian: Közgazdasági szemle), Budapest LXI. évf., 2014. December, pp. 1419-1446

Ildikó Ernszt - Zoltán Birkner - Krisztina Keller (2015): Cross-border cooperation between Hungary and Croatia: Connecting people and traditions. In: ed: Svéhlik Csaba, Very Best of KHEOPS (2006-2015): Special volume: Selection of Full papers of the Best Performances of Kheops International Scientific Conferences 2006-2015. Mór, Kheops Automotive Research Institute, 2015, pp. $492-498$. ISBN: 978-963-89779-5-3

Karlsson, C., \& Johansson, B. (2004). Towards a dynamic theory for the spatial knowledge economy. The Royal Institute of Technology Centre of Excellence for Studies in Science and Innovation.

Kaszás Nikoletta - Keller Krisztina - Birkner Zoltán (2005). Challenges facing higher education institutions along the Hungarian-Croatian border. (In Hungarian: A felsőoktatási intézmények előtt álló kihívások a magyar-horvát határ mentén). In: Ferencz Arpad (ed.) II. Management Scientific Conference: "The countryside lives and wants to live" (In Hungarian: "A vidék él és élni akar"). Kecskemét, Hungary. 2015. pp. 368-373. ISBN 978-615-5192-33-3 I. kötet, pp. 368-372.

Mulgan, G., Tucker, S., Rushanara, A., \& Sanders, B. (2007). Social innovation - What it is, why it matters and how it can be accelerated? Said Business School, University of Oxford, Oxford.

OECD (2005). Oslo manual guidelines for collecting and interpreting innovation data. Third edition. p. 46

Porter, M. E. (1985): Competitive strategy. Boston, MA: Harvard University Press.

Schumpeter, J. A. (1939). The theory of economic development. Cambridge, MA: Harvard University Press.

Szörényiné Kukorelli I. (2015). The ability of our rural areas to innovate - experiences of a research. (In Hungarian: Vidéki térségeink innovációt befogadó képessége - Egy kutatás tapasztalatai) In: Space and Society (In Hungarian: Tér és Társadalom) 29. évf., 1. szám, pp. 97-115

Vas Zs. - Bajmócy Z. (2012). The 25 years of Innovation Systems. (In Hungarian: Az innovációs rendszerek 25 éve). Economics Review (In Hungarian: Közgazdasági Szemle), LI X. évf., 2012. November: p. 1233-1256.

\section{Authors}

Zoltán Birkner, PhD is an associate professor at University of Pannonia Nagykanizsa Campus, a research specialist in the field of innovation performance of companies and regions, and the manager of a water technology research and development center.

Tivadar Máhr is an active settlement development specialist, a tourism and innovation expert, the deputy mayor of a highlighted touristic destination and PhD student in Management and Business Administration at the Doctoral School of University of Pannonia.

Nora Rodek Berkes is a lecturer at University of Pannonia Nagykanizsa Campus. She is a PhD student in Management and Business Administration at the Doctoral School of University of Pannonia. Her research topics include CSR (Corporate Social Responsibility), sustainable and responsible management, social innovation. 


\section{Spremembe v odgovornostih in nalogah univerz $v$ regionalnih inovacijskih ekosistemih}

\section{Izvleček}

Raziskovanje inovacijskega procesa se spreminja, saj postaja poleg predhodnega teritorialnega pristopa (proučevanje držav in najmanj regij) opis inovacijskega sodelovanja v lokalnih območjih vse bolj sprejet. Namesto inovacijske sposobnosti tradicionalnih velikih podjetij se je začelo proučevanje vloge malih in srednje velikih podjetij, nevladnih organizacij, lokalnih vlad, izobraževalnih institucij - še posebej univerz, kar nakazuje razvoj novega inovacijskega sistema. V letu 2015 je bila izvedena študija, v kateri smo se osredotočili na projekt civilnih in korporacijskih odnosov glavne univerze. Poskušali smo določiti nove usmeritve, ki temeljijo na ekonomskem in družbenem sodelovanju, kot tudi poiskati praktično uporabo teoretičnih helixov v teh interakcijah. Prišli smo do zaključka, da univerze niso samo deterministične glede na trojni model helix, temveč imajo tudi ugledno vlogo v ustvarjanju novega inovacijskega ekosistema, še posebej v zelo dobro opredeljenem geografskem območju.

Ključne besede: modeli helix, inovacija, družbena inovacija, odnosi univerze. 